\title{
Pengembangan Sistem Informasi Bidang Administrasi Desa Soket Dajah Kecamatan Tragah Berbasis Web
}

\author{
Sutikno' $^{1}$ Hendrik Setiawan ${ }^{2} \&$ Muhammad Aula Hijrah ${ }^{2}$ \\ ${ }^{1}$ Program Studi Ekonomi Pembangunan Fakultas Ekonomi dan Bisnis \\ ${ }^{2}$ Program Studi Pendidikan Informatika Fakultas Ilmu Pendidikan \\ Universitas Trunojoyo Madura \\ E-mail : sutikno@trunojoyo.ac.id
}

DOI: http://dx.doi.org/10.21107/pgd.v5i1.5163

\begin{abstract}
Abstrak
Artikel Diterima : 10 November 2018/ Revisi : 3 Februari 2019/Terbit : 15 April 2019

Teknologi hingga saat ini berkembang sangat pesat, sehingga pemanfaatan teknologi secara optimal dalam suatu instansi sangat diperlukan. Instansi pemerintah memiliki peran penting dalam memajukan kualitas pemerintahan, salah satunya adalah di bidang administrasi. Pengembangan suatu produk di bidang administrasi desa adalah salah satu bentuk peningkatan kualitas administrasi desa. Dengan lancarnya administrasi desa yang salah satunya adalah di bidang surat menyurat, dapat mempermudah proses administrasi yang dibutuhkan. Permasalahan yang ada diantaranya adalah pemberkasan surat masuk dan surat keluar yang sering tidak lengkap serta sulit dalam pencarian datanya Pengembangan sistem administrasi desa sangat bermanfaat, karena dengan adanya sistem administrasi berbasis web dapat mempermudah pengguna dalam melakukan proses administrasi yang dibutuhkan sesuai dengan prosedur yang telah ditetapkan. Berdasarkan keadaan tersebut kami mencoba untuk mengembangkan suatu sistem informasi administrasi desa berbasis web yang dapat mempermudah pengelolaan data surat masuk dan keluar di desa Soket Dajah.
\end{abstract}

Kata Kunci : teknologi, informasi, sistem administrasi desa, pemberkasan

\section{PENDAHULUAN}

Perkembangan teknologi saat ini telah berkembang dengan pesat. Penggunaan perangkat digital sangat banyak digunakan dalam mempermudah pekerjaan manusia. Diantaranya adalah penggunaan aplikasi yang di operasikan di komputer yang salah satunya adalah website. Penggunaan website dalam melakukan pemrosesan informasi sangatlah membantu dan bermanfaat bagi lembaga-lembaga atau perusahaan-perusahaan. Pemrosesan tersebut dapat digunakan pada beberapa bidang yang salah satunya adalah sistem administrasi.

Sistem administrasi sangat dibutuhkan dalam suatu instansi baik berupa pembukuan biasa maupun dalam bentuk digital. Sistem administrasi sangat berperan dalam perekapan data, informasi, berkas, dan beberapa hal penting yang dibutuhkan dalam pemberkasan suatu instansi. Penggunaan sistem administrasi digital telah berkembang pesat hingga saat ini, dan salah satu pengembangannya adalah berbasis web.

Administrasi berbasis web dapat membantu pegawai instansi dalam melakuan pemrosesan data sehingga perekapan data dapat dilakukan dengan cepat dan aman. Salah satu instansi yang terdapat suatu sistem administrasi adalah instansi Balai Desa yang mana sistem administrasi memang sangat berperan dalam pengolahan data desa. Melalui program KKN Tematik mandiri kelompok 27 pada semester Ganjil tahun 2018 di desa Soket Dajah, kami menemukan permasalahan pada administrasi desa yang saat ini berjalan.

Permasalahan yang ada diantaranya adalah pemberkasan surat masuk dan surat keluar yang sering tidak lengkap serta sulit dalam pencarian datanya. Arsip surat yang hanya disimpan dalam bentuk hard copy sangat rawan hilang, karena banyak berkas yang harus di simpan. Selain itu, pencatatan surat masuk dan keluar kurang efisien karena masih di tulis tangan di buku portofolio desa. Dengan demikian, dibutuhkan sebuah sistem informasi di bidang administrasi yang mampu mempermudah pengelolaan data desa tersebut. Sutabri (2012) memaparkan bahwa sistem informasi mampu mempertemukan kebutuhan pengelolaan transaksi harian yang mendukung fungsi operasi organisasi yang bersifat manajerial dengan kegiatan strategi dari suatu organisasi untuk dapat menyediakan laporanlaporan yang dibutuhkan oleh pihak luar tertentu. Berdasarkan keadaan tersebut kami mencoba untuk mengembangkan suatu sistem informasi administrasi 
desa berbasis web yang dapat mempermudah pengelolaan data surat masuk dan keluar di desa Soket Dajah.

Sistem informasi adalah suatu sistem di dalam suatu organisasi yang mempertemukan kebutuhan pengolahan transaksi harian yang mendukung fungsi operasi organisasi yang bersifat manajerial dengan kegiatan strategi dari suatu organisasi untuk dapat menyediakan laporan-laporan yang diperlukan oleh pihak luar tertentu (Sutabri, 2012). Menurut Hutahaean (2014) sistem informasi adalah suatu sistem didalam suatu organisasi yang mempertemukan kebutuhan pengelolaan transaksi, mendukung operasi, bersifat manajerial dan kegiatan strategi dari suatu organisasi dan menyediakan pihak luar tertentu dengan laporan-laporan yang dibutuhkan.

Berdasarkan beberapa uraian tersebut, dapat disimpulkan bahwa sistem informasi adalah suatu sistem dalam suatu organisasi yang mempertemukan beberapa kebutuhan yang bersifat manajerial berupa pengelolaan transaksi dan mendukung operasi yang akan menghasilkan laporan yang dibutuhkan. Sutabri (2012) memaparkan bahwa sistem informasi terdiri dari komponen-komponen yang disebut dengan istilah blok bangunan (building block), yang terdiri dari blok masukan, blok model, blok keluaran, blok teknologi, blok basis data, dan blok kendali. Penjelasan dari setiap blok tersebut tertera dalam Tabel 1.
Web adalah suatu halaman yang memuat situs-situs halaman yang berada di internet yang berfungsi sebagai media penyampaian informasi, komunikasi, atau transaksi (Hastanti et.al, 2015). Menurut Abdulloh (2016), website atau disingkat web adalah sekumpulan halaman yang terdiri atas beberapa laman yang berisi informasi dalam bentuk data digital, baik berupa teks, gambar, video audio, dan animasi lainnya yang disediakan melalui jalur koneksi internet.

Berdasarkan pengertian yang telah dipaparkan, dapat disimpulkan bahwa web adalah sebuah sistem penyebaran informasi melalui internet, dimana informasi yang dikirimkan dapat berupa teks, suara (audio), animasi, gambar dan bahkan dalam format video yang dapat diakses melalui sebuah software yang disebut browser berfungsi sebagai media penyampaian informasi, komunikasi, atau transaksi yang disediakan melalui internet.

\section{METODE}

\section{a. Analisa Kebutuhan}

Kebutuhan yang diperlukan untuk mengembangkan sistem informasi bidang administrasi desa adalah PC dengan spesifikasi procesor minimal dual core kecepatan $1.3 \mathrm{Ghz}$, RAM minimal $2 \mathrm{~Gb}$, Harddisk minimal $50 \mathrm{~Gb}$ free space, terpasang web browser dan terpasang software xampp.Selain kebutuhan dalam pengembangan, dibutuhkan pula kebutuhan fungsional yang di perlukan dalam pengembangan. Fitur yang di butuhkan dalam

Tabel 1. Macam-Macam Blok dalam Sistem Informasi

\begin{tabular}{ll}
\hline Jenis Blok & Penjelasan \\
\hline Input block & $\begin{array}{l}\text { Input mewakili data yang masuk ke dalam sistem informasi termasuk metode } \\
\text { dan media untuk menangkap data yang akan dimasukkan, yang dapat berupa } \\
\text { dokumen-dokumen dasar. }\end{array}$ \\
\hline Model block & $\begin{array}{l}\text { Terdiri dari kombinasi prosedur, logika, dan model matematik yang akan } \\
\text { memanipulasi data input dan data yang tersimpan di basis data denngan cara } \\
\text { yang sudah tertentu untuk menghasilkan keluaran yang dinginkan. }\end{array}$ \\
\hline Output block & $\begin{array}{l}\text { Produk dari sistem informasi adalah keluaran yang merupakan informasi yang } \\
\text { berkualitas dan dokumentasi yang berguna untuk semua tingkatan manajemen }\end{array}$ \\
& serta semua pemakai sistem. \\
\hline Technology block & \begin{tabular}{l} 
Teknologi merupakan tool box dalam sistem informasi yang digunakan untuk \\
menerima input, menjalankan model, menyimpan dan mengakses data, \\
menghasilkan dan mengirimkan keluaran dan membantu pengendalian sistem \\
secara keseluruhan. \\
\hline Basis data merupakan kumpulan data yang saling berkaaitan dang \\
berhubungan satu dengan yang lainnya, tersimpan di perangkat keras \\
komputer dan perangkat lunak digunakan untuk memanipulasinya. Data perlu \\
di simpan dalam basis data untuk keperluan penyediaan informasi lebih lanjut.
\end{tabular} \\
\hline Control block & $\begin{array}{l}\text { Beberapa pengendalian perlu dirancang dan diterapkan untuk meyakinkan } \\
\text { bahwa hal-hal yang dapat merusak sistem di cegah dan bila terlanjur terjadi } \\
\text { maka kesalahan-kesalahan dapat cepat di atasi. }\end{array}$ \\
\hline
\end{tabular}


sistem administrasi desa ini adalah dapat mengelola dan merekap data surat masuk dan surat keluar desa hingga proses pencetakan.

\section{b. Desain Sistem}

Desain sistem akan dirancang pada tahap ini yang mana desain dibuat menjadi tiga macam, diantaranya adalah desain alur program, use case diagram dan desain tampilan atau antar muka. Diagram alur di atas menjelaskan bahwa program dimulai dengan dilakukannya pemasukan username dan password dari pengguna. Setelah itu, dilakukan penyeleksian kondisi oleh sistem, apakah akun yang tersedia sesuai dengan username dan password yang dimasukkan. Apa bila tidak sesuai, maka akan gagal login, akan tetapi apabila sesuai, pengguna dapat mengakses fitur sistem informasi administrasi desa yang diantaranya adalah kelola menu, kelola surat masuk dan keluar, kelola data perangkat desa, kelola data user, cetak data surat masuk dan keluar, dan logout.
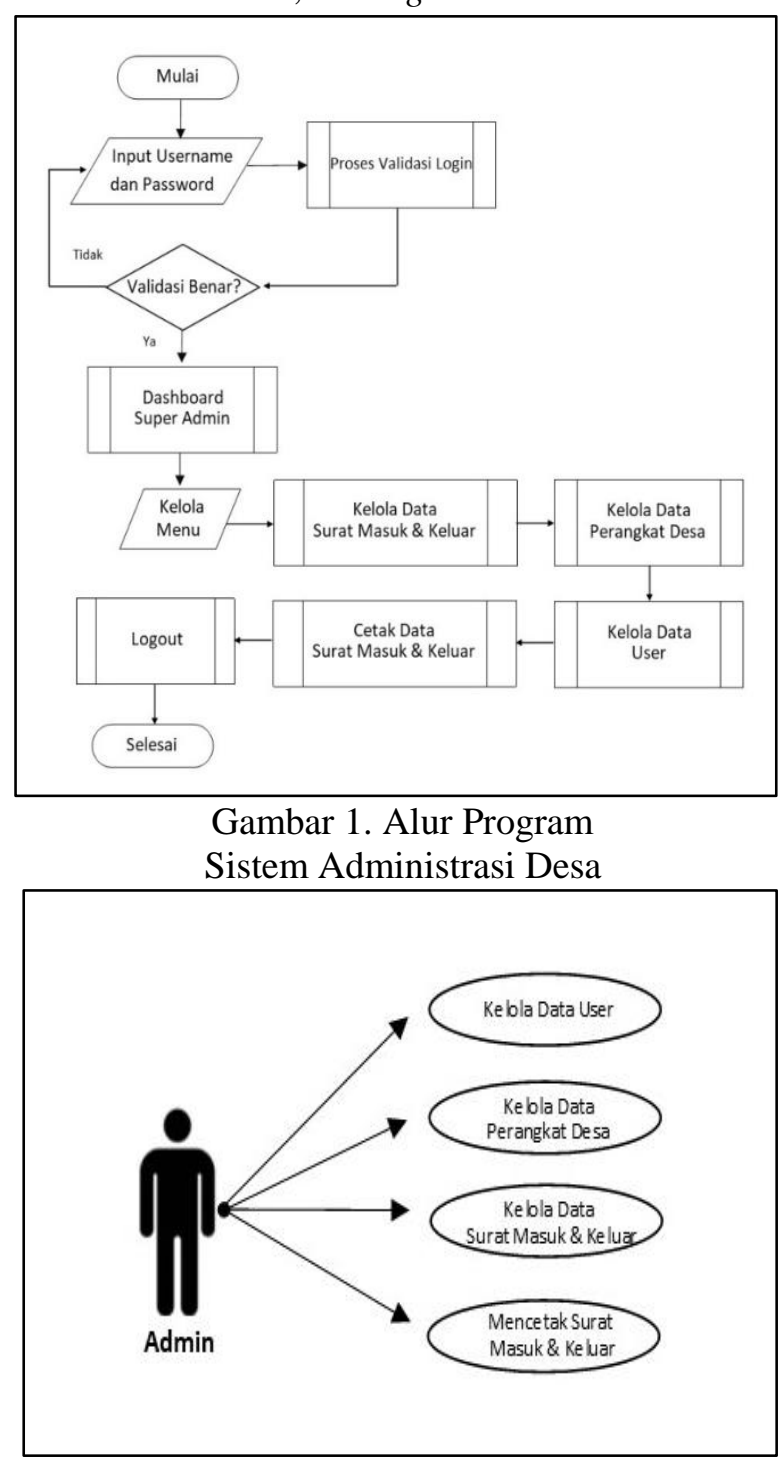

Gambar 2. Use Case Diagram
Use case diagram digunakan untuk mengetahui interaksi antara pengguna yang terjadi pada sistem informasi administrasi desa. Gambar 2 dibawah ini menjelaskan bahwa user yang bertugas menjadi admin dapat melakukkan interaksi berupa pengelolaan data user, kelola data perangkat desa, kelola data surat masuk dan keluar, dan mencetak surat masuk ataupun surat keluar.
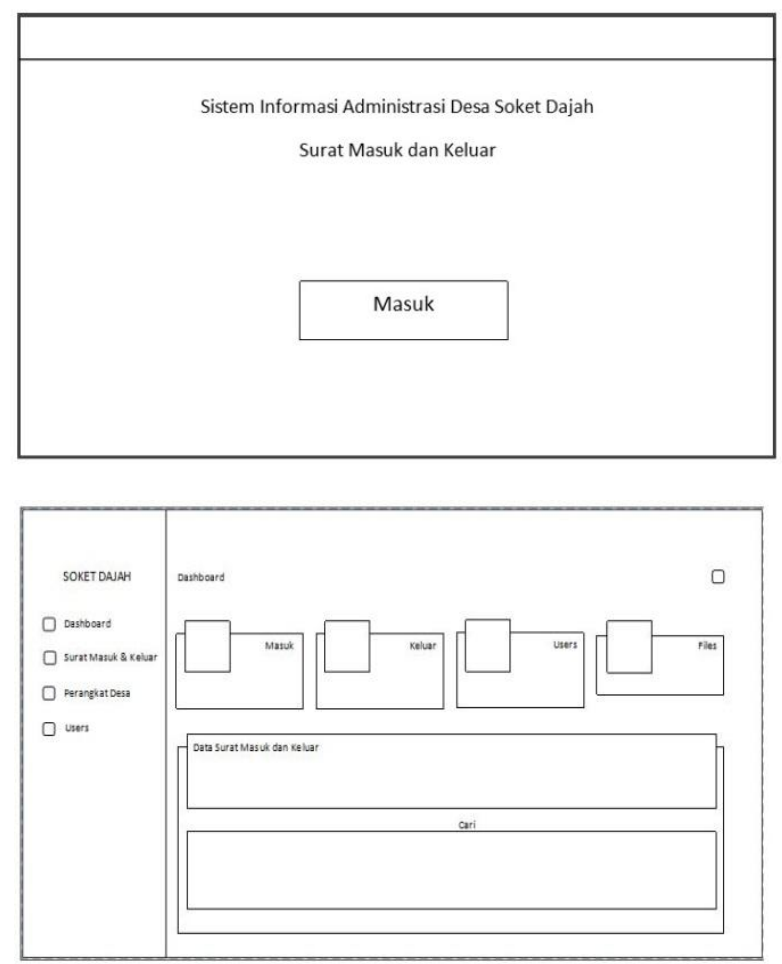

Gambar 3. Desain Interface Program

Antar muka atau dapat disebut interface dari perangkat lunak dirancang sedemikian rupa sesuai dengan kebutuhan pada perangkat lunak yang akan dikembangkan. Dengan adanya antar muka, pengguna dapat berinteraksi dengan sistem yang dikembangkan dengan baik. Rancangan antar muka dibuat dengan berdasarkan kebutuhan yang disesuaikan pada fungsional. Dengan demikian pengguna dapat memproses beberapa fungsional melalui perantara antar muka yang ada. Pada sistem informasi administrasi desa ini terdapat beberapa desain antar muka, diantaranya adalah tampilan awal, tampilan login, dan dashboard yang berisikan fitur-fitur dari sistem informasi administrasi desa.

\section{c. Implementasi dan Uji Coba}

Pada tahap ini dilakukan penerapan rancangan perangkat lunak yang telah di rancang ke dalam kode program. Proses penerapan di mulai dari pemasangan program aplikasi xampp, 
notepad ++ , dan mozilla firefox yang akan dibutuhkan dalam pengembangan perngkat lunak, penerapan metode dan prinsip yang digunakan kedalam program, hingga sistem informasi pendaftaran selesai dikembangkan.

\section{d. Integrasi dan Uji Coba Sistem}

Tahap ini bertujuan untuk menguji sejauh mana produk yang dikembangkan berfungsi. Pada tahap ini, pengembang akan melakukan pengujian terhadap produk yang dikembangkan bersama ketua pelaksana serta panitia pelaksana yang akan bertugas pada kegiatan yang akan dilaksanakan. Pengujian tersebut dilakukan dengan cara mencoba fitur-fitur yang terdapat pada produk kemudian dilanjutkan dengan dilakukan pemrosesan data sesuai dengan fitur yang ada. Dengan demikian akan diketahui kinerja dari fitur-fitur yang terdapat pada sistem informasi pendaftaran yang telah dikembangkan.

\section{e. Pengoperasian dan Pemeliharaan}

Pengoperasian sistem administrasi desa dilakukan oleh kaur umum desa Soket Dajah. Program akan di operasikan sesuai dengan fungsinya, ketika terdapat kekurangan maupun kesalahan secara fungsional maka akan dilakukan perbaikan. Ketika program telah berjalan, pengguna akan melakukan perawatan dengan selalu mengontrol kinerja sistem administrasi desa. Dengan demikian diharapkan perbaikan tersebut akan menjadikan sistem administrasi desa yang tepat guna.

\section{HASIL DAN PEMBAHASAN}

Pengembangan Sistem Informasi Administrasi Desa Soket Dajah ini menggunakan model pengembangan waterfall. Model pengembangan waterfall digunakan karena sesuai dengan karakeristik perangkat lunak yang akan dikembangkan, yang mana dalam pengembangan perangkat lunak harus melalui beberapa tahap, yaitu Requirements analysis and definition (Analisis Kebutuhan), System and software design (Desain atau Rancangan), Implementation and unit testing (Penerapan), Integration and system testing (Integrasi dan $\mathrm{Uji}$ Coba), dan Operation and maintenance (Pengoperasian dan Pemeliharaan).

Pengembangan sistem administrasi desa dilakukan dengan mengikuti tahapan-tahapan sesuai dengan model pengembangan yang sesuai dengan klasifikasi produk. Dengan demikian diharapkan program dapat dikembangkan dengan baik. Berikut ini adalah beberapa tampilan dari sistem administrasi desa yang dikembangkan.
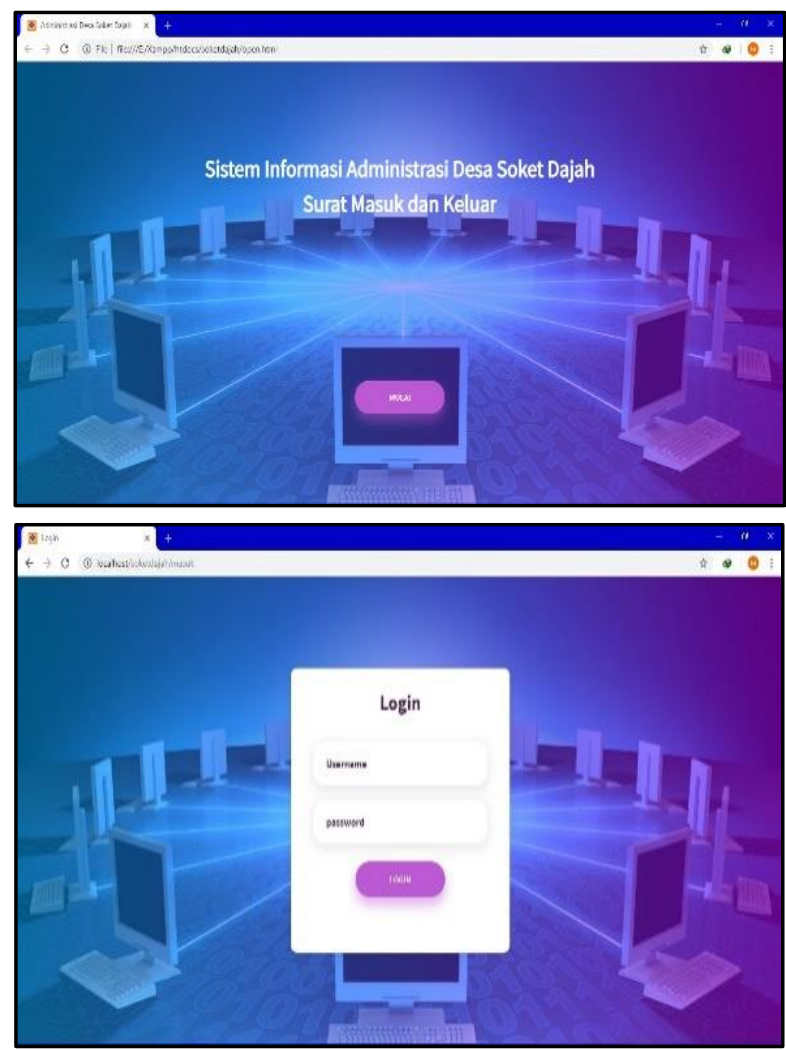

Gambar 4. Halaman Muka Sistem Informasi Administrasi Desa Soket Dajah

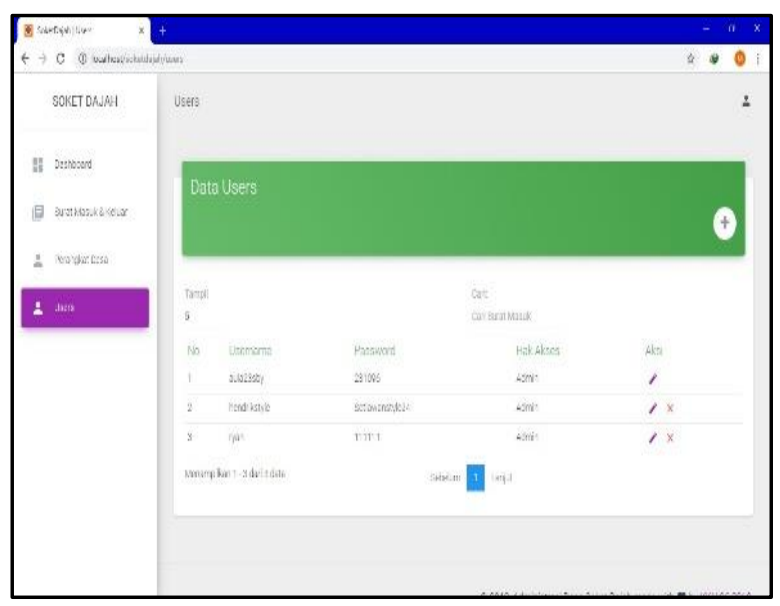

Gambar 5. Halaman untuk Data User/ Pengguna Sistem Informasi Administrasi Desa Soket Dajah

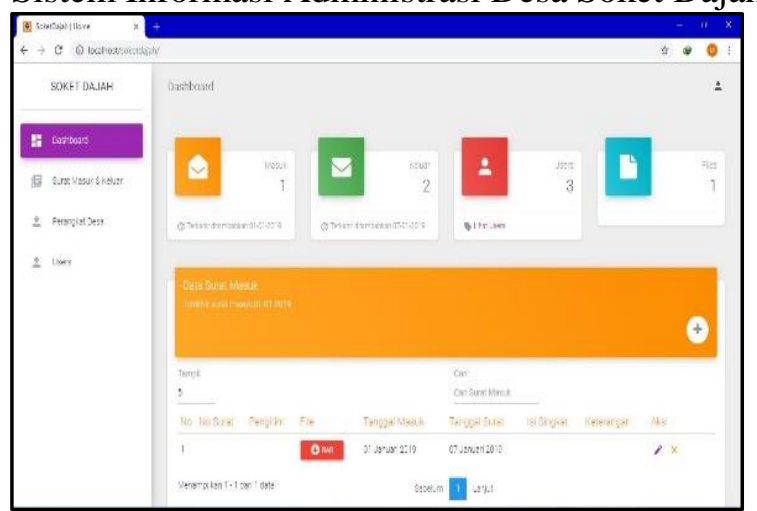



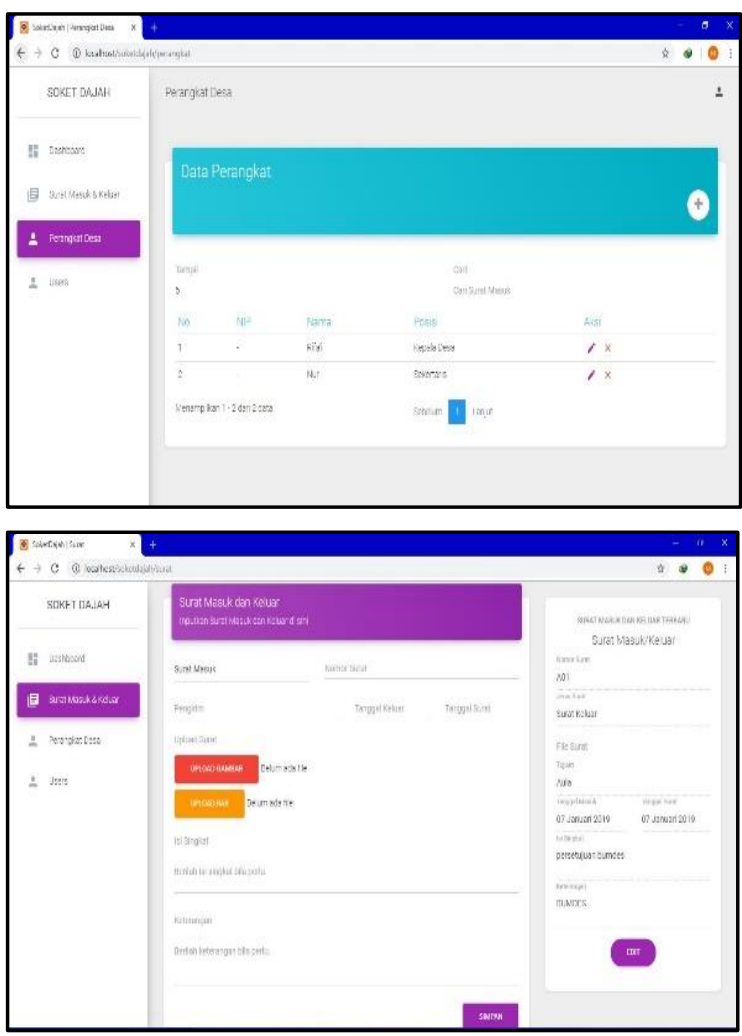

Gambar 6. Menu-Menu Utama Sistem Informasi Administrasi Desa Soket Dajah

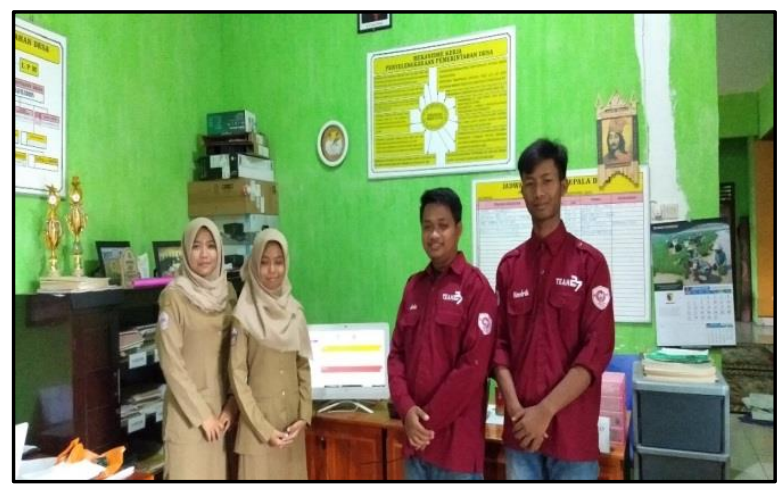

Gambar 7. Penyerahan Software Sistem

Informasi Administrasi Desa Soket Dajah

Pengembangan yang telah dilakukan menghasilkan beberapa fitur sesuai dengan kebutuhan fungsional yang telah di analisis sebelumnya. Fitur yang terdapat pada sistem administrasi desa adalah sebagai berikut :

a. Pengelolaan akun.

b. Pengelolaan data surat masuk dan surat keluar.

c. Kelola data perangkat desa.

d. Cetak data pemberkasan surat masuk dan keluar desa.

e. Penyimpanan berkas surat berupa gambar dan file kompres (.zip, .rar, .iso).

Setelah selesai dilakukan pengembangan, proses selanjutnya adalah penerapan sistem administrasi di kantor desa Soket Dajah yang selanjutnya sistem administrasi tersebut dapat di operasikan sebagaimana fungsinya.

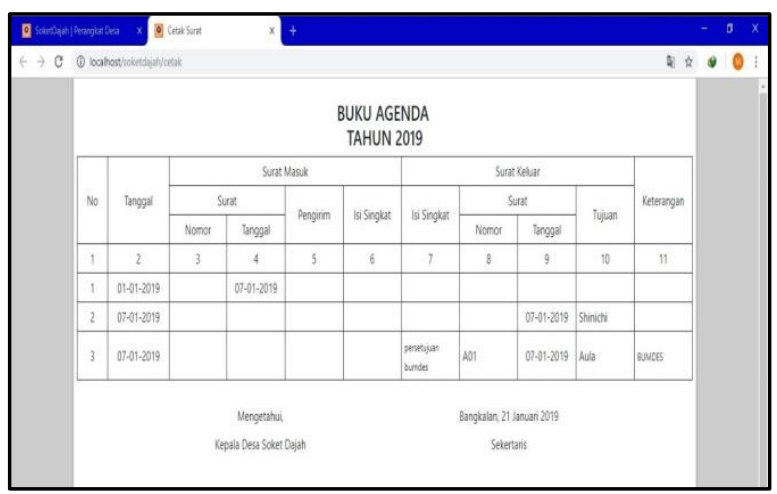

Gambar 7. Salah Satu Output dari Sistem Informasi Adminsitrasi Desa Soket Dajah
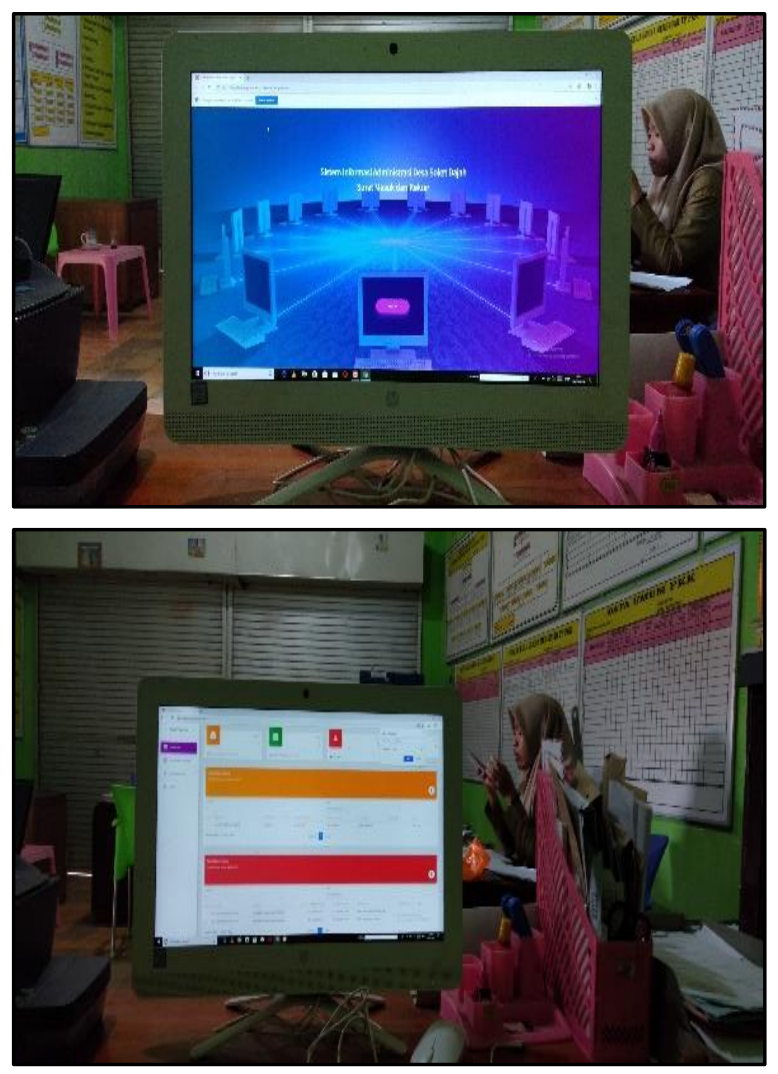

Gambar 8. Penerapan Sistem Informasi Administrasi Desa Soket Dajah di Kantor Desa

\section{KESIMPULAN}

Sistem administrasi desa yang telah dikembangkan sesuai dengan kebutuhan yang diperlukan di kantor desa Soket Dajah, karena selama ini peraangkat desa mengalami kesulitan dalam pemberkasan dan pencarian berkas surat masu dan keluar. Dengan dikembangan sistem administrasi desa berbasis web ini, dapat mempermudah perangkat desa dalam pemberkasan dan pengarsipan data serta pembukuan surat masuk dan keluar. 
DAFTAR PUSTAKA

Abdulloh, R. 2016. Easy \& Simple Web Programming Belajar Pemrograman Website Secara Efektif dan Efisien. Jakarta: Elex Media Komputindo.

Hastanti, R.P. 2015. Sistem Penjualan Berbasis Web (E-Commerce) pada Tata Distro Kabupaten Pacitan. Jurnal Bianglala Informatika Vol 3 No 2.
Hutahaean, J. 2014. Konsep Sistem Informasi. Yogyakarta : Budi Utama.

Sommerville, I. 2011. Software Engineering Ninth Edition. United States: Addison Wesley.

Sutabri, T. 2012. Analisis Sistem Informasi. Yogyakarta: Andi Offset. 